\title{
Product Branding on the Effectiveness and Performance of Manufacturing Industry
}

\author{
Adedayo Akeem Musari (Corresponding Author) \\ Department of Marketing, Gateway [ICT] Polytechnic Saapade \\ P.M.B 2004 Ode Remo, Ogun State Nigeria \\ E-mail: adexbiz@yahoo.co.uk
}

Mofoluwake Folasayo Ayo

Department of Marketing, Lead City University Ibadan, Oyo State Nigeria

E-mail: ayomofoluwake@yahoo.com

Received: September 18, 2019 Accepted: October 17, 2019 Published: November 6, 2019

doi:10.5296/bms.v10i2.15770ＵRL: https://doi.org/10.5296/bms.v10i2.15770

\begin{abstract}
The effectiveness of product branding can never be overemphasized as it affects to a large extent, the manufacturer's performance of such brand. As a result, this study examines the effectiveness of product branding on the performance of manufacturing industry using Doyin Group Nigeria Limited as a case study. A sample of 140 participants which are broken down into 20 distributors, 70 consumers and 50 staffs of the company constituted the sample size for the study conducted. The questionnaire was used as the major instrument for data collection while analysis was done based on simple percentage. The results obtained from the analysis using chi-square revealed that the product branding has a strong effect on the performance of manufacturing industry of Doyin Group Nigeria limited. The study therefore recommends that organizations should employ the use of persistent product branding for good performance on both the features and qualities of their brand to prospective customers so as to build their customer base and ensure loyalty to the brand.
\end{abstract}

Keywords: branding, product, organization, manufacturer, customer 


\section{Introduction}

Branding is an important issue in any organization. This is because without a proper branding of a firm's products, it's difficult for the firm to run its operation smoothly for profit. As consumer become more sophisticated, manufacturers place more emphasis upon promoting their brands directly to consumers (rather than to distributors) spending considerable sums on advertising the high quality of their products thus profitability. Brand was initially not focus with the aim to present to the customer the brand meaning (Roper \& Parker 2006). The success of any business or consumer product depends in part on the target markets ability to distinguish one product from another. Branding is the principal instrument used by marketers and companies to distinguish their products from that of competitors. Brands has become a tool for consumers to identity product and to get familiar with the product for further purchase of good and services (Weilbacher, 1995). To customers and individuals, a brand is defined as the combined experience processed to identify products at its regular contact (Kapferer, 2004). It is regarded perhaps that, the most distinctive skills of professional marketers are their ability to create, maintain, protect and enhance brands.

Furthermore, branding has been a major issue especially in developing countries. Branding is about making difference in product identity for patronage (Kay, 2006) As a result in order to explain the relationship between branding and profitability in developed countries. However, despite the above importance this issue failed to attract the attention of researchers in Nigeria. Thus, while searching on internet, browsing through the books and journals the researcher didn't find directly related research topics carried out in Nigeria. Manufacturers also believe that they will be less susceptible to demand from distributors for extra discount to stock their brands. For some products, considerable effort has been devoted to promoting brands to reflect the personality of their likely purchasers. Marketing research has indeed shown that for these products consumers can be persuaded to buy brands that enhance the image they have of themselves. Manufacturers believe that if they invest in the quality of their brands they will build up a brand image to which consumers will respond by asking for their goods by their brand names and by being willing to pay a premium for them. Brand serves as an avenue for companies to penetrate into a new global market, this extend the opportunity for consistence growing trend of the brand among competitive products. (Milberg \& Sinn, 2008; Loken \& Roedder 1993; Szymanski et.al 1993; Zungu et al., 2010) Hence, to adequately and effectively meet their aspirations, various marketing concepts, systems and process of product branding must be utilized to reflect the company's short and long term goals. Branding is an effective tool in marketing strategy to promote goods and services for optimum turnover and profitability of industrial and household products. Therefore, branding of goods and services calls for product differentiation in the market which originality is traceable with trademark to their respective producers.

Branding also determines the survival of organization products in the competitive business environment. In any business organization, the choice of a brand is a very critical decision as the name affects customers ${ }^{\text {ee }}$ image and attitude towards the product and the firm. The 
customer's brand loyalty of a product will remain stable as long as the brand is available in the market. (Rizwan et al., 2013). Thus, it is a contributing factor in making it a winner or loser in the competitive market. This suggests that organizations should consider a number of factors when selecting a brand name, which is one of the most difficult tasks in marketing operations. Therefore, the researchers believed that the problem is almost untouched and there is a knowledge gap on the area. It is against this background that the research seeks to investigate whether branding adds to the profitability of manufacturing company. Branding should, therefore, improve the company's image, boost sales and increase profit. Brand can establish the building brand image in the memory of the consumer as well as increasing the organizational turnover (Luo and Donthu 2006) The study limits its scope on the manufacturing sector of Nigeria only and precisely on how branding in a manufacturing sector enhances profitability. Here, attempts are made to look at concept of branding, product branding, branding strategy, effects of product branding or their significant contribution on organizational profitability.

It could therefore result into a strong and healthy relationship between the introduction of new brands and increase on returns and investments. This study focuses on branding and increased profitability and based its premises on manufacturing industries. Brand and marketing activities may convince consumers for purchasing a particular brand or product and remain loyal towards the products which in return enhance the profitability of the product. (Huy and Olsen, 2013). This study examined the impact of branding in enhancing profitability in manufacturing industries. This is with a view to highlighting the various branding strategies put in place by organizations to build, sustain and enhance profitability as well as assessing its impact on the firm.

\subsection{Objectives of the Study}

The broad objective of the study is to examine the impact of branding on profitability in manufacturing industry. To find out the extent to which manufacturers engages in sales promotional activities

- To evaluate the different branding strategies adopted by management of Doyin Nigerian Limited.

- To identify the extent that product branding has led to increase in profitability and return on investment in Doyin Nigeria Limited.

- To find out the extent to which brand name has influence on consumers purchase decisions.

\subsection{Research Hypothesis}

$\mathrm{H}_{0}$ : Branding has no significant effect on the performance of Nigerian Manufacturing Company

$\mathrm{H}_{1}$ : Branding of products has a significant effect on the performance of Nigerian manufacturing Company. 


\section{Materials and Methods}

\subsection{Research Design}

The research design facilities study the procedure for gathering the required information for the study and also states the sources of such information. Vincent, (2006) defines research design as the plan, structure and strategy of investigating, conceived so as to obtain answer to research questions and to control variables. This study used both exploratory and descriptive design. The exploratory and descriptive research design is flexible and accurate when applied on a wide range of issues. The exploratory and descriptive researches are also very important in the identification of variables by interpreting and analyzing existing conditions.

\subsection{Source of Data}

The primary and secondary sources of data were used for the study. Richard U. Uche (2006) defines a primary data as those data which are supplied by actual eye witness or a participant. They are obtained from representative samples by means of direct observation of events, manipulation of variables, resourceful plan of research situations and also performing experiments as well as responses to questionnaires. Awotunde, (2002) says "primary source of data contain eye witness account of events" the primary data involves the administration of well-structured questionnaire to some selected groups of respondents. It was used to gather information from the distributors of products of Doyin Group Nigeria Limited within Lagos and personal interview was also used to collect primary data from employees of the company

\subsection{Secondary Source of Data}

Awotunde et al (2002) defines secondary data as accounts of events given by people who are not eyewitness of or participated in the events. Richard U Uche (2006) defines a secondary data as a data which are recorded, reported or supplied by someone else who is not directly present at the actual place of occurrence, however, the facts still remains that no researcher working on this nature of research problems can afford to ignore secondary information. It is therefore used in this research work as a background and general reference material. The secondary source of information involves extracts from text books, journals and other relevant publications on the topic under consideration. The source of which have already been acknowledged by means of foot notes

There are two types of questionnaire namely; closed and open ended questionnaire. A closed ended questionnaire or fixed response type restricts a respondent to some response option whereas am open ended or free response type questionnaire does not provide response option for the respondents. In this type of questionnaire relevant questions are provided for the respondents to supply necessary answers in their own way.

\subsection{Population of Study}

Population is regarded to be the groups of people living in a particular territory. The term population in a research work is used to cover all members or elements that define a group. 
Asika (2016) defines a population as all conceivable elements, subjects or observations relating to a particular phenomenon of interests to a researcher. Ezejule and Ogwo (2013) defines a population of study as the group usually of people or things, set of individuals, objects of measurements about whom you want to be able to draw conclusion. The study population here comprises of selected distributors, consumers and staffs of Doyin Group Nigeria Limited. The study population is 150 broken down.

\subsection{Sample Size}

Sample size is the total number of elements of the population that are selected for a closer study. In this research, a total of 140 persons which are broken down into 20 distributors, 70 consumers and 50 staffs of the company will constitute the sample size. A total number of 140 questionnaires were distributed of which 20 out of the 140 were directed to the Distributors of Doyin Group Nigeria Limited, 50 questionnaires were distributed to the staff of Doyin Group Nigeria Limited and the 70 questionnaire represents $50 \%$ of the total sample size were directed to the consumers of Doyin Group Nigeria Limited.

\subsection{Data Analysis}

In order to analyze the data collected effectively, a simple method of tabulation and percentage will be employed also the chi square method of statistical analysis was used for analysis.

\section{Results}

The respondent response would be presented in a tabular and chi-square would be used in analyzing it. The researches chose to use percentage technique and chi-square in organizing, presenting and interpreting the data collected because it provides for a simpler and more effective understanding of the data presented. One hundred and forty questionnaires were distributed, and all were filled and returned. The analyses of questionnaires are here by presented in the table below:

Table 1. Socio economic characteristics of branding strategies

\begin{tabular}{llcc}
\hline Parameters & Options & Frequency & Percentage (\%) \\
\hline Gender (sex) & Male & 90 & 64.28 \\
& Female & 50 & 35.71 \\
\hline Marital Status & Single & 82 & 58.57 \\
& Married & 48 & 34.28 \\
& Divorce & 10 & 7.14 \\
\hline Age & $21-30 y r s$ & 60 & 42.85 \\
& $31-40 y r s$ & 34 & 24.28 \\
& $41-50 y r s$ & 20 & 14.28 \\
& 51yrs and above & 26 & 18.57 \\
\hline Position/Level & Top Level & 30 & 21.42
\end{tabular}




\begin{tabular}{llcc}
\hline & Middle Level & 40 & 28.57 \\
& Lower Level & 70 & 50 \\
\hline Educational status & SSCE/GCE & 20 & 13.33 \\
& NCE/ND & 30 & 21.42 \\
& BSc/HND & 70 & 50 \\
& Others & 20 & 14.28 \\
\hline Working Experience & Below 1-5yrs & 115 & 82.14 \\
& 6-10yrs & 20 & 14.28 \\
& 11yrs and above & 15 & 10.71 \\
\hline
\end{tabular}

Source: Field Work 2018

Table 1 show that, $64.28 \%$ of the respondents are male while $35.71 \%$ are female. It also reveals that $58.7 \%$ of the respondents are single, $34.28 \%$ are married and $7.14 \%$ is divorced. shows that 60 respondents are 21 - 30 years which represents a total of $42.85 \%$, while 34 respondents are of the age of 31-40 years which represents a total of $24.28 \%$ and 20 respondents are of the age of 41-50 years which represents a total of $14.28 \%$ and 26 respondent are of the age 51 years and above which represents a total of $18.57 \%$. This indicates that majority of the respondent are of the age 21-30yrs. Table 1 reveals that, 30 respondents occupies the rank of the top level management which represents a total of $21.42 \%, 40$ respondents occupies the middle level which represents a total of $28.57 \%, 70$ respondents occupies the rank of lower level which represents a total of 50\%. Furthermore, 20 respondents have SSCE holders which represents 13.33\%, 30 respondents have NCE/ND holders representing a total of $21.42 \%$ and 70 respondents have HND/B.Sc. which is representing $50 \%$ of the total respondents, while 20 representing $14.28 \%$ possess other qualifications. These indicate that majority of the respondent are literate since they possess BSc/HND. Tables 1 further shows that, 115 respondents has below 1-5 years working experience while 20 has 6-10 years working experience which represents $82.14 \%$ and $14.28 \%$ respectively and 15 respondent representing $10.71 \%$ has $11 \mathrm{yrs}$ and above working experience. These indicate that majority of the respondent have below 1-5years working experience.

Table 2. Branding strategies of consumer product

\begin{tabular}{llcc}
\hline Branding strategies & Option & Frequency & Percentage (\%) \\
\hline Branding type & Excellent & 47 & 94 \\
& Very Good & 3 & 6 \\
\hline $\begin{array}{l}\text { What is the company branding } \\
\text { strategic objective }\end{array}$ & Meet Competition & 15 & 30 \\
& & & \\
& Consumers & 25 & 50 \\
& Satisfaction & & \\
& Profitability & 10 & 20 \\
\hline Branding profitability & Strongly Agree & 22 & 44 \\
& Agree & 15 & 30
\end{tabular}




\begin{tabular}{|c|c|c|c|}
\hline & Disagree & 5 & 10 \\
\hline & Indifferent & 8 & 16 \\
\hline \multirow{2}{*}{$\begin{array}{l}\text { Has the company branding } \\
\text { objective help in achieving } \\
\text { profitability? }\end{array}$} & Strongly Agree & 40 & 80 \\
\hline & Agree & 10 & 20 \\
\hline \multirow[t]{3}{*}{ Distribution system satisfaction } & Yes & 33 & 66 \\
\hline & Partially & 10 & 20 \\
\hline & Fairly & 7 & 14 \\
\hline \multirow{4}{*}{$\begin{array}{l}\text { Distributive nature and customer } \\
\text { satisfaction }\end{array}$} & Yes & 30 & 60 \\
\hline & Partially & 10 & 20 \\
\hline & Fairly & 5 & 10 \\
\hline & No & 5 & 10 \\
\hline \multirow{2}{*}{$\begin{array}{l}\text { Satisfaction } \\
\text { product }\end{array}$} & Strongly Agree & 43 & 86 \\
\hline & Agree & 7 & 14 \\
\hline
\end{tabular}

Source: Field Work 2018

Table 2 shows that 47 which represent $94 \%$ of the total respondents agree that branding is excellent in the organization, while 3 respondents, represents $6 \%$ of the respondents agree that branding of Doyin Group Nigeria Limited is very good. Table 2 shows that 15 which represent $30 \%$ of the total respondents agree that meeting competition is the company branding strategy objective, 25 which represents $50 \%$ of the respondents agree that consumer satisfaction is the company branding strategy objective, while 10 which represent $20 \%$ agree that profitability is the company branding strategy objective.

Table 2 shows that 22 which represent $44 \%$ of the total respondents strongly agree that branding enhance profitability, 15 representing 30\% agreed, 5 which represents 10\% disagreed, while 8 representing $16 \%$ gave a different opinion that branding of Doyin Group Nigeria Limited products profitability. Table 2 shows that 40 which represent $80 \%$ of the total respondents strongly agree that branding the company branding objective help in achieving profitability while 10 respondents representing $20 \%$ agree that the company branding objective help in achieving profitability. Table 2 shows that which represents $66 \%$ of the total respondent are satisfied with the distributive system of the company while 10 which represent $20 \%$ of the respondents are partially satisfied with the distributive system of the company. 7 which represent $14 \%$ of the respondents are fairly satisfied with the distributive system of the company and no respondent are not satisfied with the distributive system of the company.

Table 2 reveals that 30 which represents $60 \%$ of the respondents believes that distributive nature of the company's products leads to consumers satisfaction while 10 which represents $20 \%$ of the respondents partially believes that distributive nature of the company's product 
leads to consumers satisfaction. $10 \%$ of the respondents fairly believe while $10 \%$ of the respondents do not believe that distributive nature of the company's product leads to consumer's satisfaction. Table 2 indicates that 43 which represent $86 \%$ of the respondents strongly agreed that they are satisfied with the company's product while 7 which represent $14 \%$ of the respondents are agreed that they are satisfied with the company's product.

Table 3. Distributors questions

\begin{tabular}{|c|c|c|c|}
\hline Distributors questions & Option & Frequency & Percentage $(\%)$ \\
\hline \multirow{3}{*}{$\begin{array}{l}\text { What type of customers are you } \\
\text { with Doyin group Nigeria limited }\end{array}$} & Distributor & 10 & 50 \\
\hline & Sub-Distributor & 5 & 25 \\
\hline & Merchant Company & 5 & 25 \\
\hline \multirow{4}{*}{$\begin{array}{l}\text { Number of years of being a } \\
\text { customer }\end{array}$} & Less than 2 yrs & 4 & 20 \\
\hline & $2-5 \mathrm{yrs}$ & 7 & 35 \\
\hline & $5-10 y r s$ & 5 & 25 \\
\hline & $11 y r s$ and above & 4 & 20 \\
\hline \multirow{2}{*}{$\begin{array}{l}\text { Are you satisfied with company } \\
\text { product }\end{array}$} & Strongly Agree & 13 & 65 \\
\hline & Agree & 7 & 35 \\
\hline How product are received? & By road & 20 & 100 \\
\hline \multirow[t]{3}{*}{ Distribution system satisfaction } & Yes & 14 & 70 \\
\hline & Partially & 4 & 20 \\
\hline & Fairly & 2 & 10 \\
\hline \multirow{3}{*}{$\begin{array}{l}\text { Prompt delivery and consumer's } \\
\text { satisfaction }\end{array}$} & Yes & 17 & 85 \\
\hline & Partially & 2 & 10 \\
\hline & Fairly & 1 & 5 \\
\hline
\end{tabular}

Source: Field Work 2018

Table 3 show that 10 which represents $50 \%$ of the total respondents is a distributor, 5 which represents $25 \%$ of the respondents is a sub-distributor, 5 which represents $25 \%$ of the respondents is a merchant company. Table 3 shows that 4 which represent $20 \%$ of the total respondents have been customer for less than 2 years. 7 which represent $35 \%$ of the total respondents have been a customer for 2-5 years. 5 which represent $25 \%$ of the total respondents have been a customer for 5-10 years, while 4 which represent $20 \%$ of the total respondents have been a customer for 11years and above. Table 3 shows that 13 which represent $65 \%$ of the respondents strongly agreed that they are satisfied with the company's product while 7 which represent $35 \%$ of the respondents are agreed that they are satisfied with the company's product. Table 3 shows that 20 which represent $100 \%$ of the total population receive the company's product by road while no respondents receive the 
company's product by air, rail or sea.

Table 3 shows that which represents $70 \%$ of the total respondent are satisfied with the distributive system of the company while, which represents $20 \%$ of the respondents are partially satisfied with the distributive system of the company. 2 which represent $10 \%$ of the respondents are fairly satisfied with the distributive system of the company and no respondents is not satisfied with the distributive system of the company. Table 3 shows that 17 which represents $85 \%$ of the total respondents. Agrees that prompt delivery of the company product increases consumer's satisfaction while 2 which represent $10 \%$ of the respondents agree that prompt delivery of the company's product will partially increases consumer's satisfaction. 1 which represents $5 \%$ of the total respondents fairly agree that prompt delivery of the company product will fairly leads to consumers satisfaction while no respondent agree that prompt delivery of the company product will increase satisfaction agrees that prompt delivery of the company's product will increase satisfaction.

Table 4. Consumer questions

\begin{tabular}{|c|c|c|c|}
\hline Consumer questions & Option & Frequency & Percentage $(\%)$ \\
\hline \multirow{4}{*}{$\begin{array}{l}\text { Number of years consuming } \\
\text { company's product }\end{array}$} & $1-5$ years & 40 & 57.14 \\
\hline & $6-10$ years & 10 & 14.28 \\
\hline & $11-15$ years & 10 & 14.28 \\
\hline & Above 15 years & 10 & 14.28 \\
\hline Consumer's incentives from & Yes & 25 & 35.71 \\
\hline \multicolumn{4}{|l|}{ Doyin group Nigeria limited } \\
\hline & Partially & 30 & 42.85 \\
\hline & Fairly & 5 & 7.14 \\
\hline & No & 10 & 14.28 \\
\hline \multirow[t]{4}{*}{ Types of incentives } & Gift item & 40 & 57.14 \\
\hline & Free Soaps and & 20 & 28.57 \\
\hline & Detergent & & \\
\hline & None & 10 & 14.28 \\
\hline \multirow{4}{*}{$\begin{array}{l}\text { What attracted you to the product } \\
\text { of Doyin group Nigeria limited? }\end{array}$} & Brand name & 35 & 50 \\
\hline & $\begin{array}{l}\text { Availability } \\
\text { product }\end{array}$ & 10 & 14.28 \\
\hline & Advertisement & 20 & 28.57 \\
\hline & Price & 5 & 7.14 \\
\hline \multirow{3}{*}{$\begin{array}{l}\text { Distributive nature and customer } \\
\text { satisfaction }\end{array}$} & Yes & 50 & 71.42 \\
\hline & Partially & 10 & 14.28 \\
\hline & Fairly & 10 & 14.28 \\
\hline effective channel management & Yes & 42 & 60 \\
\hline
\end{tabular}


and consumers satisfaction

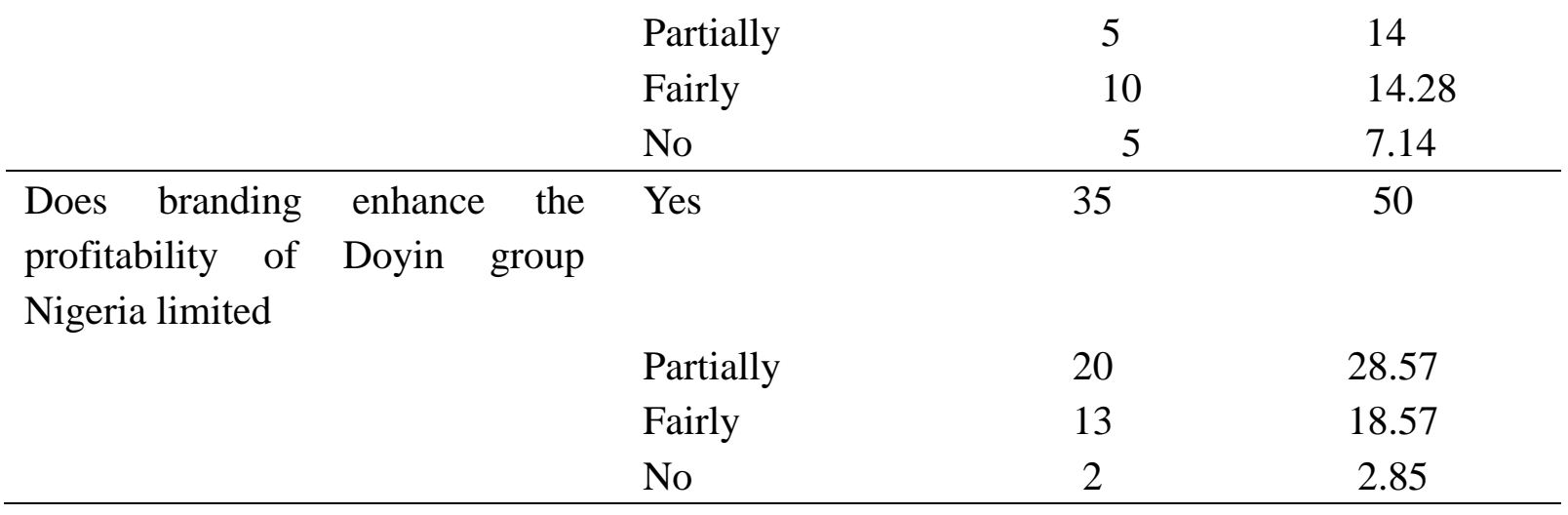

Source: Field Work 2018

Table 4 shows that 40 which represent $57.14 \%$ of the total respondents have been consuming the company's product between 1-5 years. 10 which represent $14.28 \%$ of the total respondents have been consuming the company's product between 6-10years. 10 which represent $14.28 \%$ of the total respondents have been consuming the company's product between 11-15years while 10 which represent $14.28 \%$ of the total respondents have been consuming the company's product for 15 years and above. Table 4 shows that 25 which represent $35.71 \%$ of the total respondents receive incentives from Doyin group Nigeria Limited. 30 which represent $42.85 \%$ of the total respondents have partially received incentives from Doyin Group Nigeria Limited. 5 which represent $7.14 \%$ of the total respondents have fairly received incentives from Doyin Group Nigeria Limited and 10 which represent $14.28 \%$ of the total respondents do not receive incentive from Doyin Group Nigeria Limited.

Table 4 shows that no respondents receives cash as incentives from the company while 40 which represents $57.14 \%$ of the respondents received gift items from the company. 20 which represent $28.57 \%$ of the total respondents have received free products from the company while 10 which represent $14.28 \%$ of the total respondents have neither received cash, gift items nor free products from the company. Table 4 shows that 35 which represent $50 \%$ of the total respondents are attracted to the company's products because of its brand name. 10 which represent $14.28 \%$ of the total respondents are attracted to the company's product because of the availability of the product. 20 which represents $28.57 \%$ of the respondents are attracted to the company's product because of advertisement while $7.14 \%$ of the respondents sees price as a factor that attracts them to the company's product.

Table 4 shows that 50 which represents $71.42 \%$ of the respondents believes that distributive nature of the company's products leads to consumers satisfaction while 10 which represents $14.28 \%$ of the respondents partially believes that distributive nature of the company's product leads to consumers satisfaction. $10 \%$ of the respondents fairly believe that distributive nature of the company's product leads to consumer's satisfaction Table 4 shows that 42 which represents $60 \%$ of the total respondents believes that effective channel 
management leads to consumers satisfaction while 5 which represents $14 \%$ of the respondents partially believes that effective channel management creates consumers satisfaction. 5 which represents $14.28 \%$ of the respondents fairly believes that effective channel management leads to consumers satisfaction while 5 which represents $7.14 \%$ of the total respondents do not believe that channel management leads to consumers satisfaction

Hypothesis testing: the hypothesis formulated to guide this study will be tested. To test this hypothesis, the chi-square statistical method was informed by the fact that the formulated hypothesis involved the personal view and assessment of the respondents

$\mathbf{H}_{\mathbf{0}}$ : Branding has no significant effect on the profitability of Doyin Group Nigeria Limited.

$\mathbf{H}_{1}$ : Branding of products has a significant effect on the profitability of Doyin Group Nigeria Limited.

Computation of expected frequency (E)

$\mathrm{E}=\mathrm{N} / \mathrm{n}$

Where; $\mathrm{N}=$ Total Number of Respondents, $\mathrm{n}=$ number of options available,

Therefore, $\mathrm{E}=70 / 4=17.5$

From the value obtained in the observed frequency and expected frequency, the value of the Chi-

Square will be obtained using the formula below

Where $\mathrm{X}^{2}=$ Chi-square

$\Sigma i=$ summation of all items

ei $=$ Expected frequency

$0 \mathrm{i}=$ sample size (observed frequency)

One terms used

$\mathrm{N}=$ number of responses or option

$\mathrm{df}=$ degree of freedom

$\mathrm{H}_{0}=$ hypothesis zero

$\mathrm{H}_{\mathrm{i}}=$ Hypothesis one 
Table 5. Chi-square Evolution

\begin{tabular}{lccccc}
\hline Options & Number of Respondents & $\mathrm{E}$ & {$[\mathrm{O}-\mathrm{E}]$} & {$[\mathrm{O}-\mathrm{E}]^{2}$} & {$[\mathrm{O}-\mathrm{E}]^{2} / \mathrm{E}$} \\
\hline Yes & 35 & 17.5 & 17.5 & 306.25 & 17.5 \\
partially & 20 & 17.5 & 2.5 & 6.25 & 0.35 \\
Fairly & 13 & 17.5 & -4.5 & -20.25 & -1.15 \\
No & 2 & 17.5 & -15.5 & -240.25 & -13.72 \\
Total & 35 & 17.5 & & & 2.98 \\
\hline
\end{tabular}

$X^{2}=17.5+0.35-1.15-13.72=2.98$

In order to test the hypothesis the degree of freedom has to be calculated using this formula

$\mathrm{DF}=(\mathrm{c}-1)(\mathrm{r}-1)$ Where:

$\mathrm{c}=$ number of Column, $\mathrm{r}=$ Number of rows, $\mathrm{c}=4$ and $\mathrm{r}=2$

Therefore, $(4-1)(2-1)=(3)(1)=3$

Level of significance of the study is $5 \%$ which is equal to 0.05

From the critical value table, the degree of freedom of 3 under $0.05=7.81$

We now compare the value of $\mathrm{X}^{2}$ which is equal to 2.98 and that of the critical value table which is 7.81

The decision rule states that if the calculated value of X2 is greater than the table value, then the study will accept the formulated hypothesis which is the alternate hypothesis and reject the null hypothesis, while if the table value is more than X2 then we accept the null hypothesis and reject the alternate (Lucey,2012)

Hence, in this situation, $\mathrm{X}^{2}$ value which is 2.98 is lower than that of the table value which is 7.81 as a result, we accept the null hypothesis and reject the alternate.

\section{Decision Rules:}

Reject $\mathrm{H}_{0}$ if $\mathrm{r}$ is greater (>) than critical value. Otherwise, reject $\mathrm{H}_{1}$.

0.05 is selected as the significant level having 95\% confidence level. Degree of freedom (d) $=0.05$ for $(\mathrm{n}-2)$.

Meanwhile, with the use of twelve (12) list of item/figures, we will have; 12-2=10.

Therefore, we have 0.05 significant level at 10 degree of freedom.

The regression formula is shown below:

$\mathrm{r}=$ regression $\quad \mathrm{n}=$ number of items $\mathrm{x}=$ assumed value $\quad \mathrm{y}=$ value derived

From the research questionnaire distributed, summation of respondents view on the question 
(Questions 7, 11 and 25) were selected randomly from section B and section C. this 3 questions will be tabulated to compute the analysis for our result.

\begin{tabular}{|l|l|l|l|l|l|}
\hline $\mathrm{N}$ & $\mathrm{X}$ & $\mathrm{Y}$ & $\mathrm{XY}$ & $\mathrm{X}^{2}$ & $\mathrm{Y}^{2}$ \\
\hline 1 & 4 & 5 & 20 & 16 & 25 \\
\hline 2 & 3 & 16 & 48 & 9 & 256 \\
\hline 3 & 2 & 32 & 64 & 4 & 1024 \\
\hline 4 & 1 & 47 & 47 & 1 & 2209 \\
\hline 5 & 4 & 49 & 196 & 16 & 2401 \\
\hline 6 & 3 & 32 & 96 & 9 & 1024 \\
\hline 7 & 2 & 7 & 14 & 4 & 49 \\
\hline 8 & 1 & 12 & 12 & 1 & 144 \\
\hline 9 & 4 & 43 & 172 & 16 & 1849 \\
\hline 10 & 3 & 37 & 111 & 9 & 1369 \\
\hline 11 & 2 & 8 & 16 & 4 & 64 \\
\hline 12 & 1 & 12 & 12 & 1 & 144 \\
\hline & 30 & 300 & 808 & 90 & 10558 \\
\hline
\end{tabular}

Table 6. Coefficients of variables

\begin{tabular}{|c|c|c|c|c|c|c|}
\hline \multicolumn{7}{|c|}{ Coefficients $^{\mathrm{a}}$} \\
\hline \multirow{3}{*}{\multicolumn{2}{|c|}{ Model }} & \multirow{2}{*}{\multicolumn{2}{|c|}{$\begin{array}{l}\text { Unstandardized } \\
\text { Coefficients }\end{array}$}} & \multirow{3}{*}{$\begin{array}{l}\text { Standardized } \\
\text { Coefficients } \\
\text { Beta }\end{array}$} & \multirow[t]{3}{*}{ t-test } & \multirow[t]{3}{*}{ Sig. } \\
\hline & & & & & & \\
\hline & & $\mathrm{B}$ & Std. Error & & & \\
\hline \multirow{2}{*}{1} & (Constant) & 15.333 & 11.903 & & 1.288 & .227 \\
\hline & $\mathrm{X}$ & 3.867 & 4.346 & .271 & .890 & .395 \\
\hline
\end{tabular}

\begin{tabular}{|l|l|l|l|l|l|}
\hline \multicolumn{2}{|l|}{ Model Summary } & $\mathrm{R}$ & R Square & $\begin{array}{l}\text { Adjusted R } \\
\text { Square }\end{array}$ & $\begin{array}{l}\text { Std. Error of the } \\
\text { Estimate }\end{array}$ \\
\hline 1 & $.271^{\mathrm{a}}$ & .073 & -.019 & 16.834 \\
\hline a. Predictors: (Constant), $\mathrm{x}$
\end{tabular}

\section{Discussion}

The result above drawn from the parameters giving (0.05 significant level at 10 degree of freedom) that has the critical value 1.81 on the r-Distribution Table and the calculated table ( $\mathrm{r}$ $=0.271$ ) has proved the following:

Rejects null $\left(\mathrm{H}_{0}\right)$ because the critical value is greater than the calculated value from drawn table. 
Accepts alternative $\left(\mathrm{H}_{1}\right)$ because the critical value is lesser than the calculated vale from the drawn above table.

This research project has continuously tried to emphasize the fundamental essence of enhancing profitability through product branding among manufacturing companies in Nigeria. In the course of this study, Doyin Group Nigeria Limited was adopted as the case study with the aim of trying to analyze its product brand in enhancing profit and increase in sales. The study findings clearly indicates that branding of Doyin Group Nigeria Limited product is one of the determinants of sales and continuous increase in return on investment. The research instruments used for data collection was personal interview and the administration of questionnaire. The sample size used for the work is 140 comprising of 50 staffs of Doyin Group Nigeria Limited, 20 distributors of the company's product and 70 consumers of the company's product. Finally, the percentages and Chi- Square was used in analyzing and presentation of data. The data collected from the administered questionnaire which were then interpreted and analyzed using the percentage and Chi- Square method. After the interpretation and analysis, the null hypothesis was accepted and the alternate hypothesis was rejected, since the value which is 2.98 is smaller than the table value.

\section{Conclusions}

It is evident that principles of enhancing profitability tools and techniques are quite applicable and have been used in Doyin Group Nigeria Limited companies in Nigeria like any other industry that deals with tangible and intangible products. Market has been segmented so also the customers and products were differentiated to the target markets that results into different brands both heavy customers and light customers with the aim of increasing profit among manufacturing industry.

Doyin Group Nigeria Limited has been able to retain and motivate its channel members thereby increasing the market position of the organization. The company management has been able to improve its knowledge of the needs of its consumers and fine turning its strategies to quickly adjust to changes in the environment. The company should refrain from loading the distributors with excessive inventories but providing adequate sales potential, monitoring distributors profits to ensure that their channels remain financially viable. The company should embrace the marketing strategies of constantly innovating and improving their products to increase consumer's satisfaction. A strong intelligence network should be maintained to enable the company monitor the activities of competitors in the industry on regular basis. The management of the company should explore every opportunity possible to create innovation which motivates its distributors and consumers of its products with a view of having competitive advantage.

\section{Recommendation}

Branding is one of the determinants of sales in Doyin Group Nigeria Limited. Because of this, competitors may want to imitate the brand in order to forestall the occurrence of competitors imitating the brand of Doyin Group Nigeria Limited. The branding should be done in such a 
way that it cannot be imitated. It was observed that the problem of improper financing, planning, poor branding and insufficient sales can be revered. This can be achieved through proper allocation and use of funds and accurate planning and forecasting techniques to be used by management. Good branding strategies should be adopted to enhance profitability and sales volume. Finally, employees ${ }^{e e}$ loyalty should be maintained by adequate monetary and nonmonetary rewards. The company should keep abreast of developments in the labor market as a means of ensuring rewards viz-a-viz other manufacturing companies. This is because, equipment no matter how sophisticated they are must be operated by people and finally frustrated employees are a threat to a company's profit enhancement.

\section{References}

Asiegbu, I. F., Awa, H. O., Akpotu, C., \& Ogbonna, U. B. (2011). Salesforce competence development and marketing performance of industrial and domestic products firms in Nigeria. Far East Journal of Psychology and Business, 2(3), 43-59.

Balmer, J. M., Mukherjee, A., Greyser, S. A., Jenster, P., \& Kay, M. J. (2006). Strong brands and corporate brands. European journal of marketing.

Baridam, D. M. (2001). Research methods in administrative sciences. Port Harcourt: Sherbrooke Associates.

Blois, K. (2000). The Oxford Textbook of Marketing. Oxford: Oxford University Press.

Blom, C. (2005). Stretcher in de supermarkt [Stretching at the supermarket]. SWOCC publicatie, (32).

Brassington, F., \& Pettitt, S. (2000). Principles of Marketing ( $2^{\text {nd }}$ Ed.). Great Britain: Pearson Education, Limited.

Buday, T. (1989). Capitalizing on brand extensions. Journal of Consumer Marketing, 6(4), 27-30. https://doi.org/10.1108/EUM0000000002559

Czinkota, M., \& Ronkainen, I. (2001). International Business (6th Ed.). Fort Worth: Harcourt College.

Dahlberg, E., Kulluvaara, C., \& Tornberg, J. (2004). Brand extensions: Case studies of three Swedish Companies.

Davidson, J. H. (1987). Offensive marketing or, how to make your competitors followers. Penguin Books Ltd., Harmonds worth.

Davis, S. (2002). Brand Asset Management2: how businesses can profit from the power of brand. Journal of consumer marketing, 19(4), 351-358. https://doi.org/10.1108/07363760210433654

Dike. H. I. (2004). The A B C of Research Methods in Education. Pan Unique Nigeria Ltd, Capiic Publishers, Port Harcourt. 
Grime, I., Diamantopoulos, A., \& Smith, G. (2002). Consumer evaluations of extensions and their effects on the core brand: Key issues and research propositions. European journal of marketing, 36(11/12), 1415-1438. https://doi.org/10.1108/03090560210445245

Huy Tuu, H., \& Ottar Olsen, S. (2013). Consideration set size, variety seeking and the satisfaction-repurchase loyalty relationship at a product category level. Asia Pacific Journal of Marketing and Logistics, 25(4), 590-613. https://doi.org/10.1108/APJML-09-2012-0102

James, W. B., \& James, V. K. (2007). Research in Education. Asoke K. Ghosh, Prentice hall of India. New Delhi.

Kalu, S. E. (1998). Marketing Management: Planning, Execution and Control. Port Harcourt: University of Port Harcourt Press Ltd.

Kapferer, J. N. (1995). Strategic brand management: over het eigen vermogen van merken [about brand equity]. Academic Service, Schoonhoven.

Kapferer, J. N. (2001). Reinventing the Brand. London: Kogan Page Limited. Keller, K.L. (1998). Strategic Brand Management. USA: Prentice Hall, Inc.

Kapferer, J. N. (2004). Brand NEW world, brand equity. The Economic Times, June, 30, 7.

Kapferer, J. N. (2008). The new strategic brand management: Creating and sustaining brand equity long term. Kogan Page Publishers.

Keller, K.L. (1998). Strategic Brand Management. USA: Prentice Hall, Inc.

Kim, C. K., \& Lavack, A. M. (1996). Vertical brand extensions: current research and managerial implications Journal of Product \& Brand Management, 5(6), 24-37. https://doi.org/10.1108/10610429610152813

Kotler, P. (1997). Marketing Management (9th ed.). USA: Prentice Hall, Inc.

Kotler, P., \& Armstrong, G. (1996). Principles of Marketing (7th ed.). USA: Prentice Hall, Inc.

Loken, B., \& John, D. R. (1993). Diluting brand beliefs: when do brand extensions have a negative impact?. Journal of marketing, 57(3), 71-84. https://doi.org/10.1177/002224299305700305

Luo, X., \& Donthu, N. (2006). Marketing's credibility: A longitudinal investigation of marketing communication productivity and shareholder value. Journal of Marketing, 70(4), 70-91. https://doi.org/10.1509/jmkg.70.4.70

Milberg, S. J., \& Sinn, F. (2008). Vulnerability of global brands to negative feedback effects. Journal of Business Research, 61(6), 684-690. https://doi.org/10.1016/j.jbusres.2007.06.045

Nijssen, E. J. (1999). Success factors of line extensions of fast-moving consumer goods. European Journal of Marketing, 33(5/6), 450-474. 
https://doi.org/10.1108/03090569910262044

Nilson, H. T. (1998). Competitive Branding-Winning the Marketplace with Value Added Brands. Chichester: Wiley,cop.

O'sullivan, D., \& Abela, A. V. (2007). Marketing performance measurement ability and firm performance. Journal of marketing, 71(2), 79-93. https://doi.org/10.1509/jmkg.71.2.79

Park, C. W., Lawson, R., \& Milberg, S. (1989). Memory structure of brand names. ACR North American Advances, 16(1), 726-731.

Park, C. W., McCarthy, M. S., \& Milberg, S. J. (1993). The effects of direct and associative brand extension strategies on consumer response to brand extensions. ACR North American Advances, 20(1), 28-33.

Park, C. W., Milberg, S., \& Lawson, R. (1991). Evaluation of brand extensions: the role of product feature similarity and brand concept consistency. Journal of consumer research, 18(2), 185-193. https://doi.org/10.1086/209251

Patel, R., \& Tebelius, U. (1987). Om forskningsprocessen, I Patel, R. Tebelius, U.(red), Grundbok i forskningsmetodik (s 41-48). Lund: Studentlitteratur.

Pitta, D. A., \& Prevel Katsanis, L. (1995). Understanding brand equity for successful brand extension. Journal of consumer marketing, 12(4), 51-64. https://doi.org/10.1108/07363769510095306

Randall, G. (1997). A Practical Guide to Branding: Planning, Organizing and Strategy. London: Kogan Page Limited.

Randall, G. (2000). Branding: A practical guide to planning your strategy. Kogan Page Limited.

Reddy, M., Terblanche, N., Pitt, L., \& Parent, M. (2009). How far can luxury brands travel? Avoiding the pitfalls of luxury brand extension. Business Horizons, 52(2), 187-197. https://doi.org/10.1016/j.bushor.2008.11.001

Riezebos, R. (2002). Brand management (theory and application of the development, management and protection of brands and brand portfolios). Wolters Noordhoff, Groningen

Rizwan, M., Akbar, I., Muqtadir, A., Shafique, U., Zia, H., Naseer, W., \& Amin, S. A. (2013). Impact of brand switching, brand credibility, customer satisfaction and service quality on brand loyalty. IOSR Journal of Business and Management, 1, 12-20.

Rogers, B. (2003). What gets measured gets better. Journal of Targeting, Measurement and Analysis for Marketing, 12(1), 20-26. https://doi.org/10.1057/palgrave.jt.5740095

Saunders, M., Lewis, P., \& Thombill, A. (2000). Research Methods for Business Students. Harlow: Pearson Education Limited. 


\section{Macrothink}

Sood, S., \& Drèze, X. (2006). Brand extensions of experiential goods: Movie sequel evaluations. Journal of Consumer Research, 33(3), 352-360. https://doi.org/10.1086/508520

Spiegel, M. R. (2004). Theory and Problems of Statistics. New York: McGraw-Hill Book Company.

Szymanski, D. M., Bharadwaj, S. G., \& Varadarajan, P. R. (1993). Standardization versus adaptation of international marketing strategy: an empirical investigation. Journal of marketing, 57(4), 1-17. https://doi.org/10.1177/002224299305700401

Weilbacher, W. M. (1995). Brand Marketing, NTC Business Books, Chicago, IL, p. 4. Milberg.

\section{Copyright}

Copyright for this article is retained by the author(s), with first publication rights granted to the journal.

This is an open-access article distributed under the terms and conditions of the Creative Commons Attribution license (http://creativecommons.org/licenses/by/4.0/). 